\title{
Régis Bonvicino
}

Como você pensa a relação entre o tempo literário e o tempo histórico?

$\mathrm{O}$ tempo literário deve durar mais do que o tempo histórico, caso contrário não chega a se configurar como literário, haja vista, como exemplos de contemporâneos bem-sucedidos de suas épocas, que permaneceram, Camilo Pessanha, Cesário Verde, Mário de Sá-Carneiro, Fernando Pessoa, Carlos Drummond de Andrade, João Cabral, Murilo Mendes e outros. No entanto, sem o tempo presente não há poesia, mas algo inominável, chamado de poesia. $\mathrm{O}$ poeta que não enfrenta as dificuldades do contemporâneo ou o seu tempo histórico acaba por mimetizar o contemporâneo de ontem - o que ocorre à farta na poesia brasileira atual. Ela poderia, perfeitamente, não existir! Sua inutilidade e/ou desnecessidade advém desse epigonismo - o contemporâneo de ontem e anteontem, dos modernismos, concretismos, surrealismos, popismos, caetanismos por meio da tropicália etc. etc. etc. Uma vez Drummond disse que havia se cansado de ser moderno e queria ser eterno. $O$ equilibrio entre tempo histórico e tempo literário torna um autor eterno e moderno na acepção de contemporâneo: "O novo que permanece novo". Pessoalmente, se tivesse que escolher, sob riscos, ficaria com o tempo histórico, porque só ele me permite a invenção e não a mera dedução de uma poesia imitada do "literário".
Quais procedimentos sua obra adota diante de um mundo em que predominam a ação econômica e a espetacularização da arte?

Adoto os procedimentos da crítica, de ser crítico ante a economia e a espetacularização da arte; adoto, também, técnicas de contraste, de violência. Aliás, retomando, o inominável, que se chama de poesia ora produzida no Brasil, este inominável é pouco crítico e bastante fâmulo. Ele, esse monstro chamado poesia brasileira atual, mimetiza, às avessas, a espetacularização da arte: muita autopromoção e nenhuma criação e/ ou invenção, isto é, sem sentido crítico. Andy Wharol acertou: os artistas preferem a fama à lama.

\section{Qual reflexão sua obra produz sobre a tradição literária brasileira?}

Por uma questão ética, não me permito falar sobre o meu próprio trabalho. Prefiro remeter os leitores de Teresa ao meu website, onde poderão encontrar alguns escritos de outros sobre o que produzo: $<$ http://regisbonvicino.com.br $>$. E igualmente prefiro falar por meio do poema "Prosa", que ora envio como parte da resposta.

\section{Prosa}

Um poema não se vende como música, não se vende como quadro, como canção, ninguém dá um centavo, uma fava, um poema não vive além de suas palavras, sóis às avessas, não se vende como prosa, só como história ou arremedo de poema, não se vende como ferro-velho, pedaços de mangueira de um jardim, tambores de óleo queimado, sequer um pintassilgo, cantando no aterro de lixo ou a língua negra dos esgotos, que floresce algas, não se vende como grafite, não se vende como foto, vídeo ou filme de arte, não se vende como réplica ou post-card, mau negociante de inutilidades, me tenha impregnado da praga das palavras. 


\section{Como você pensa a forma literária?}

A partir de um diálogo entre a tradição literária e o agora, num confronto violento entre eles. $\mathrm{O}$ que produzo é muitíssimo diferente do que João Cabral produziu, mas sinto-me próximo dele, em todos os aspectos (menos na grandeza); não falo de mim em meus poemas. E dou importância ao acabamento formal de um poema. Se fosse um poeta norte-americano, gostaria de ter sido um objetivista (William Carlos Williams, George Oppen sobretudo). Dou importância à linguagem e procuro juntar conteúdos à forma, mensagens às formas.

Os primeiros livros de Régis Bonvicino (1955) encontram-se reunidos em Primeiro tempo (Perspectiva, 1995). Dirigiu as revistas de poesia Qorpo estranho-com três números-,Poesiaem grevee muda. Fundou, em 2001, e codirige, ao lado de Charles Bernstein e Idalia Morejón, a revista Sibila (<http://www.sibila.com.br>), publicada atualmente pela Martins Editora. Seus três primeiros livros estão reunidos em Primeiro tempo (Perspectiva, 1995). Página órfä, poemas foi editado em 2007 (Martins Fontes). 